\title{
Influence of treatment in multiple sclerosis dysability

\author{
An open, retrospective, non-randomized \\ long-term analysis
}

\author{
Lineu Cesar Werneck, Paulo José Lorenzoni, Vitor A. Radünz, \\ Marco A.T. Utiumi, Cláudia Suemi Kamoi Kay, Rosana Herminia Scola
}

\begin{abstract}
Correspondence
Lineu Cesar Werneck

Serviço de Neurologia

Hospital de Clínicas da UFPR

Rua Gal. Carneiro 181 / Sala 310

80060-900 Curitiba PR - Brasil

E-mail: werneck@ufpr.br
\end{abstract}

\section{Support}

This study is part of the research project in $\mathrm{MS}$ genomics funded by the $\mathrm{CNPq}$ (Brazilian National Research Council). No pharmaceutical industry gave any support to this study and it was design, conducts and analyzed by the authors

\section{Conflicts of interest}

Lineu Cesar Werneck received honoraria for speaking from Merck-Serono, Roche Pharmaceuticals and BoeringherIngelheim and research grant from Abbott-Biogen and TRB-Pharma. Rosana Herminia Scola received honoraria for consultation and speaking from Merck-Serono and research grant from Bayer-Schering. The other authors declare that they have no conflicts of interest

Received 27 November 2009

Received in final form 23 February 2010 Accepted 2 March 2010

\begin{abstract}
The efficacies of immunosuppressive (IMS) and immunomodulatory (IMM) drugs for multiple sclerosis (MS) have been reported in several studies. These agents can reduce relapse rates and lesions observed by magnetic resonance imaging studies. However, the effect of these medications in disability progression over 4 years is rarely examined. Objective: To study the disabilities associated with MS patients after a long time period and to analyze the therapeutic influence of different types of treatments in patient disease progression. Method: This is an open, uncontrolled, non-randomized, retrospective study of the disease progression using the Expanded Disability Status Scale (EDSS) and the Multiple Sclerosis Severity Score (MSSS) in 155 cases of MS, which were $76 \%$ female with a mean age of onset of $30.21 \pm 9.70$. The follow-up period was $115.39 \pm 88.08$ months (median 92, 3 to 447 months). These cases were submitted to the following 277 different therapeutic procedures: 62 without IMS or IMM therapy (SYT) (just corticosteroids), 53 with azathioprine (AZA), 53 interferon- $\beta$ (IFN $\beta$ )- $1 \mathrm{~b} 250 \mu \mathrm{g}$ (BET), 55 IFN $\beta-1 \mathrm{a} 22 \mu \mathrm{g}$ (R22), 19 IFN $\beta$-1a $30 \mu \mathrm{g}$ (AVO), 15 IFN $\beta$-1a $44 \mu \mathrm{g}$ (R44), 15 glatiramer acetate (COP) 20 mg, and 5 cases with mitoxantrone (MIT). Results: The median EDSS group was 2.00 ( 0 to 5.5, mean $1.89 \pm 1.52)$ at the onset of each treatment and 2.50 ( 0 to 9, mean 3.06 \pm 2.18$)$ at the end. The median initial MSSS was $3.34(0.25$ to 9.50 , mean $3.94 \pm 2.91)$ and the final medial was 3.90 ( 0.05 to 9.88, mean 4.02 22.78). The EDSS between initial and final score for the whole group had statistically significant progression, as well as for the sub-groups SYT, AZA, BET and R22. No statistically significance difference was found in the MSSS between initial and final scores in the whole group or treatment sub-groups. The variation between the initial and final EDSS and MSSS among the types of treatments found no statistical significance for any group. Conclusion: In this study series, no statistical difference was found in the long-term progression of disability among the IMS and IMM treated cases, nor in the cases treated only with corticosteroids.
\end{abstract}

Key words: multiple sclerosis, immunomodulatory therapy, immunosuppressive therapy, EDSS, multiple sclerosis disability, multiple sclerosis treatment.

Influência do tratamento na incapacidade da esclerose múltipla: estudo aberto, retrospectivo e não randomizado em longo prazo

\section{RESUMO}

A eficácia das medicações imunossupressivas (IMS) e imunomoduladoras (IMM) na esclerose múltipla (MS) tem sido relatada em diversos estudos. Essas medicações podem reduzir o número de surtos e de lesões observadas nos estudos de ressonância magnética. Entretanto, o efeito dessas medicações na progressão da incapacidade em período acima de quatro anos é raramente estudado. Objetivo: Estudar a incapacidade associada à MS em longo prazo e analisar os benefícios dos diferentes tipos de tratamento na progressão

Unit of Demyelinating Diseases, Neurology Division, Internal Medicine Department, Hospital de Clínicas, Universidade Federal do Paraná (UFPR), Curitiba PR, Brazil. 
da doença. Método: Estudo aberto e retrospectivo da progressão da incapacidade utilizando a escala expandida do grau de incapacidade (EDSS) e o escore da gravidade da esclerose múltipla (MSSS) em 155 casos de MS, sendo 76\% do sexo feminino, idade

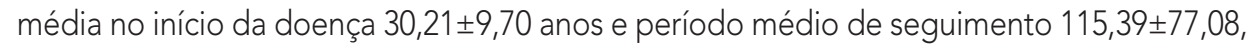
mediana 92 ( 3 a 447) meses. Os casos foram submetidos a 277 tipos diferentes de tratamentos: 62 casos não usaram IMS ou IMM, somente corticosteróides (SYT); $53 \mathrm{com}$ azatioprina (AZA); 53 com interferon- $\beta$ (IFN $\beta$ )-1b $250 \mu \mathrm{g}$ (BET); 55 com IFN $\beta-1 \mathrm{a} 22 \mu \mathrm{g}$ (R22); 19 com IFN $\beta$-1a $30 \mu \mathrm{g}$ (AVO); $15 \mathrm{com}$ IFN $\beta-1$ a $44 \mu \mathrm{g}$ (R44); $15 \mathrm{com}$ acetato de glatiramer (COP) 20 mg, e 5 casos com mitoxantrone (MIT). Resultados: A mediana do EDSS do grupo foi 2,0 ( 0 a 5,5, média total do grupo foi 1,89 1,52$)$ no início de cada tratamento e 2,50 (0 a 9, média de 3,06 22,18$)$ no fim. A mediana inicial da MSSS foi 3,34 (0,25 a 9,50,

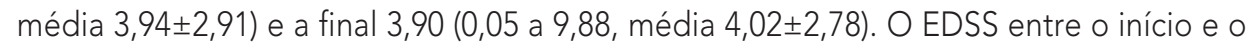
fim do tratamento do grupo mostrou progressão estatisticamente significante e também para os subgrupos SYT, AZA, BET e R22. Não foi encontrada diferença estatística no MSSS entre o início e fim do tratamento no grupo total ou nos subgrupos. Não foi encontrada diferença estatisticamente significante entre a variação inicial e final do EDSS e MSSS entre os diversos subgrupos de tratamento. Conclusão: Nesta série, não foi encontrada diferença estatística na progressão da incapacidade em longo prazo entre os IMS e IMM, bem como nos casos tratados unicamente com corticosteróides.

Palavras-chave: esclerose múltipla, terapêutica imunomoduladora, terapêutica imunossupressiva, EDSS, incapacidade na esclerose múltipla, tratamento da esclerose múltipla.

The progressive disability in multiple sclerosis (MS) remains a therapeutic problem despite numerous medications available. In attempt to interfere with the natural course of this disease, which is marked by inflammatory and immunological abnormalities, immunosuppressive (IMS) drugs have been used for its treatment. One of the first IMS drugs used was azathioprine (AZA), which was given orally at $3 \mathrm{mg} / \mathrm{kg}$ q.o.d. However, in relation to placebo, this drug only showed modest effectiveness in follow up periods ranging between 1.5 and 3 years ${ }^{1-4}$. More recently, the intravenous use of mitoxantrone (MIT) given at $120 \mathrm{mg}$ IV for 18 months showed effectiveness in follow up periods between 2 and 5 years. However, MIT has been reserved for cases that do not respond to immunomodulator (IMM) drugs because of its toxicity ${ }^{5,6}$.

In the last decade, IMM drugs have been introduced for the treatment of relapsing-remitting forms of MS, and several studies have been done to study their effectiveness. Most of these studies reported a reduction in the number of MS relapses over a follow-up period of two to three years as criteria for drug effectiveness ${ }^{7}$. The main studies compared the test compound versus placebo or another drug, such as interferon beta (IFN $\beta$ ) -1b 250 $\mu$ g q.o.d., SC $(\mathrm{BET})^{8}$, IFN $\beta-1 \mathrm{a} 30 \mu$ g q.w., IM $(\mathrm{AVO})^{9-11}$, IFN 3 -1a $22 \mu \mathrm{g}$ (R22) and $44 \mu \mathrm{g}$ SC t.i.w. (R44) ${ }^{12}$, AVO and $\mathrm{R} 44^{13,14}, \mathrm{BET}$ and $\mathrm{AVO}^{15}$, glatiramer acetate $20 \mathrm{mg}$ q.d. SC $(\mathrm{COP})^{16}, \mathrm{R} 44$ and $\mathrm{COP}^{17}$, or, $\mathrm{BET}$ and $\mathrm{COP}^{18}$.

Additional criteria often used to demonstrate the effectiveness of these medications have included the reduction of inflammatory activity or newly visible MRI lesions in relation to the placebo group ${ }^{19}, \mathrm{BET}^{20}, \mathrm{R}^{2} 2^{21}, \mathrm{COP}^{22}$, $\mathrm{AZA}^{23}$ or $\mathrm{MIT}^{6}$ groups.

Regarding the progression of MS associated disability; most studies have reported little change in the Expanded Disability Status Scale (EDSS) ${ }^{8,24}$ or reduced disease progression compared with placebo groups ${ }^{9-16,25}$. In addition, some studies have attempted to assess MS associated disabilities for longer periods (4 years), but results is difficult to analyze because the participating patients decreased progressively over the follow up period ${ }^{26,27}$. A study using only the placebo arm from 31 different randomized trials failed to validate any effects on disease progression because the follow up time was too short and/or the effects on disease disability were too small to obtain a reliable result ${ }^{28}$.

Over the natural course of the disease, MS patients evolve from relapsing-remitting forms to secondary progressive forms, when numbers of relapses tend to reduce or disappear with an apparent reduction in disease activity, thereby resulting in variable disease progression and apparent stabilization ${ }^{29}$. More recently, a new score was developed based on the initial EDSS score and the time of disease progression for each patient. This was called Multiple Sclerosis Severity Score (MSSS) and was developed from a data collection of 9,982 patients, comparing the EDSS of on individual with the disability distribution score in cases with similar disease duration ${ }^{30}$.

This work presents the long-term ( $>9.5$ years) disease progression and associated disabilities of a group of MS patients. These subjects were treated at a typical Univer- 
sity Medical Center and were retrospectively examined to determine whether some types of therapy used to treat MS influenced the degree of disability progression using the EDSS and MSSS.

\section{METHOD}

We retrospectively review all the 247 patients charts with the diagnosis of MS seen in our hospital. To include patients in the study, they must have met the following inclusion criteria: records with complete clinical and laboratory data information regarding disease evolution, EDSS ${ }^{24}$ grade registered in the record during the clinical visit or data to enable proper analysis of the EDSS before 1997 (when the study began), a disease evolution compatible with MS diagnosis, a MRI consistent with MS, relapsing-remitting MS as initial form, an initial EDSS $\leq 5.5$, and continuous treatment with the same drug for at least for 3 months. The following exclusion criteria were implemented: records with incomplete or conflicting data, primary progressive form, clinically isolated syndrome, neuromyelitis optica, lack of a thorough clinical investigation to rule out diseases that mimic MS and two drugs used simultaneously.

A group of patients who did not receive IMM or IMS drugs was included in this study and was called the symptomatic treatment (SYT) group. This SYT group included newly diagnosed cases that had experienced a remission in clinical symptoms, a good therapeutic response to prednisone or methylprednisolone during relapses, a long interval between the second and third relapse, or side effects from other medications (off IMS or IMM more than three months to be included in this group), or were from a period before the availability of IMM drugs or refused to use prescribed medications.

Relapses were treated in a subgroup of patients by corticosteroid administration, which took the form of either intravenous methylprednisolone (pulse therapy) or oral prednisone. These treatments were used for at least 30 days and then discontinued in the following months with an improvement of symptoms. These drugs were not considered as a unique treatment group, because steroid administration was used in all groups during exacerbation.

We evaluated 247 records, but 92 patients were excluded because their records were incomplete and it was not possible to assess the development of MS associated disabilities and therapies used. We included only 155 patients with a MS diagnosis who used 277 different therapeutic procedures for their treatment. There was no specific protocol to introduce the medication, usually after the patient meets the diagnostic criteria. The choose of medication changes from drug availability, introduction of new drugs in the market, Government supplied or preference for one of the several physicians in charge of patients over the years. After the introduction of one type of medication, it was changed if the patient had two or more relapses per year and showed progression in disease

Table 1. Types of treatment, age, duration of disease for 155 cases of multiple sclerosis with 277 different therapeutic procedures.

\begin{tabular}{|c|c|c|c|c|c|}
\hline Type of treatment & $\mathrm{N}^{\circ}$ & $\%$ & $\begin{array}{l}\text { Age onset treatment } \\
\text { (years). Mean, SD, } \\
\text { median (range). }\end{array}$ & $\begin{array}{c}\text { Duration disease } \\
\text { (months). Mean, SD, } \\
\text { median (range). }\end{array}$ & $\begin{array}{c}\text { Duration treatment } \\
\text { (months). Mean, SD, } \\
\text { median (range). }\end{array}$ \\
\hline $\begin{array}{l}\text { Symptomatic } \\
\text { treatment }\end{array}$ & 62 & 22.4 & $\begin{array}{l}29.82 \pm 9.28 \\
29.00(12-49)\end{array}$ & $\begin{array}{l}13.84 \pm 33.03 \\
0.00(0-193)\end{array}$ & $\begin{array}{l}51.48 \pm 63.00 \\
28.00(3-324)\end{array}$ \\
\hline $\begin{array}{l}\text { Azathioprine } \\
\text { (3 mg/kg q.d., PO) }\end{array}$ & 53 & 19.1 & $\begin{array}{l}35.58 \pm 9.27 \\
37.00(16-54)\end{array}$ & $\begin{array}{l}54.04 \pm 68.84 \\
29.00(1-324)\end{array}$ & $\begin{array}{l}67.64 \pm 58.68 \\
48.00(4-312)\end{array}$ \\
\hline $\begin{array}{l}\text { Interferon beta } 1 b \\
(250 \mu \text { g q.o.d., SC) }\end{array}$ & 53 & 19.1 & $\begin{array}{l}33.94 \pm 9.46 \\
33.00(17-55)\end{array}$ & $\begin{array}{l}77.45 \pm 87.20 \\
48.00(3-381)\end{array}$ & $\begin{array}{l}36.75 \pm 29.44 \\
2700(3-132)\end{array}$ \\
\hline $\begin{array}{l}\text { Interferon beta } 1 \mathrm{a} \\
(22 \mu \mathrm{g} \text { t.i.w SC) }\end{array}$ & 55 & 19.9 & $\begin{array}{l}34.45 \pm 10.60 \\
33.00(15-56)\end{array}$ & $\begin{array}{l}54.22 \pm 66.00 \\
29.00(1-300)\end{array}$ & $\begin{array}{l}33.25 \pm 24.52 \\
29.00(3-102)\end{array}$ \\
\hline $\begin{array}{l}\text { Interferon beta 1a } \\
(30 \mu \mathrm{g} \text { q.w. IM) }\end{array}$ & 19 & 6.9 & $\begin{array}{l}36.37 \pm 10.07 \\
35.00(18-58)\end{array}$ & $\begin{array}{l}69.21 \pm 82.35 \\
36.00(3-308)\end{array}$ & $\begin{array}{c}19.95 \pm 13.62 \\
18.00(6-64)\end{array}$ \\
\hline $\begin{array}{l}\text { Interferon beta 1a } \\
(44 \mu g \text { t.i.w., SC) }\end{array}$ & 15 & 5.4 & $\begin{array}{l}35.93 \pm 10.30 \\
39.00(19-48)\end{array}$ & $\begin{array}{c}75.67 \pm 67.86 \\
42.00(12-206)\end{array}$ & $\begin{array}{l}31.67 \pm 20.03 \\
28.00(6-72)\end{array}$ \\
\hline $\begin{array}{l}\text { Glatiramer acetate } \\
(20 \text { mg q.d., SC) }\end{array}$ & 15 & 5.4 & $\begin{array}{l}34.27 \pm 11.21 \\
35.00(15-51)\end{array}$ & $\begin{array}{l}55.47 \pm 42.51 \\
48.00(1-132)\end{array}$ & $\begin{array}{c}22.33 \pm 16.91 \\
21.00(4-72)\end{array}$ \\
\hline $\begin{array}{l}\text { Mitoxantrone } \\
\text { (120 mg in } 18 \text { months, IV) }\end{array}$ & 5 & 1.8 & $\begin{array}{l}32.00 \pm 12.08 \\
33.00(19-50)\end{array}$ & $\begin{array}{l}58.00 \pm 31.13 \\
63.00(23-96)\end{array}$ & $\begin{array}{l}11.80 \pm 6.34 \\
12.00(6-22)\end{array}$ \\
\hline Total & 277 & 100 & $\begin{array}{c}33.69 \pm 9.98 \\
33.00(12-58)\end{array}$ & $\begin{array}{l}51.92 \pm 68.60 \\
29.00(0-381)\end{array}$ & $\begin{array}{c}42.61 \pm 4.80 \\
27.00(3-324)\end{array}$ \\
\hline
\end{tabular}


disability (an irreversible increase more than one point in the EDSS over 6 months period) or adverse drug effects.

The sample consisted of 155 patients (118 female and 37 male) with an age onset ranging from 12 to 55 years (median 29.00, mean 30.21 \pm 9.70 ), and there was a predominance of young female patients in this series. The time of follow-up varied between 3 to 447 months (median 92, with a mean of $115.39 \pm 88.08$ months).

Eligible patients were separated into eight groups (SYT, AZA, MIT, AVO, R22, R44, BET and COP) according to the time they remained in the same type of treatment (Table 1).

If the patients changed the treatment type, only the time period when they remained in the original treatment group was considered for analysis. In the new treatment group, the patient was considered as a new patient and the evaluation was from the beginning of the treatment to the time the patient remained in this new group. Some patients received two or more types of one treatment at different times, but were excluded if they had therapy combinations (two types of treatment at the same time). No overlap of treatment was allowed and if occurred, the case was excluded from the study. Relevant data included the age at onset, gender, clinical evaluation, time of disease progression, initial EDSS score (at treatment type onset), final EDSS score (evaluation at end of type treatment), time of the treatment, and modality of treatment (SYT, AZA, BET, R22, AVO, R44, COP and MIT). All the patients received the same amount of medication despite the age, gender, weight and disease duration (Table 1).

Also, using the EDSS and know disease duration, we classified each patient in the multiple sclerosis severity score (MSSS), using the spread-sheet described by Roxburg et al. ${ }^{30}$.

The data were analyzed using descriptive statistical methods such as the Student " $\mathrm{t}$ " test, Pearson's correlation, Mann-Whitney U test and Wilcoxon signed ranks test.

\section{RESULTS}

The median initial EDSS of the 155 cases was 2.00 ( 0 to 5.5 ) and the mean was $1.89 \pm 1.52$, and the final median was 2.50 (0 to 9.0) with mean of $3.06 \pm 2.18$. The median initial MSSS was 3.34 (0.25 to 9.50) with the mean of $3.94 \pm 2.91$, and the final median was 3.90 (0.05 to 9.88) with the mean $4.02 \pm 2.78$. The correlation (Pearson) between the final EDSS and time of disease progression for the whole group was $0.373(\mathrm{p}<0.01)$ (Fig 1) and for the final MSSS was -0.035 ( $\mathrm{p}=0.664$ ) (Fig 2). During the follow-up, 78 cases had only one treatment type (SYT 7 cases, AZA 20 cases, BET 22 cases, R22 20 cases, AVO 2 cases, R44 4 cases, COP 3 cases), and the remaining 77 cases had two or more types of treatment at different times, but never at the same time (52 cases with two treatment

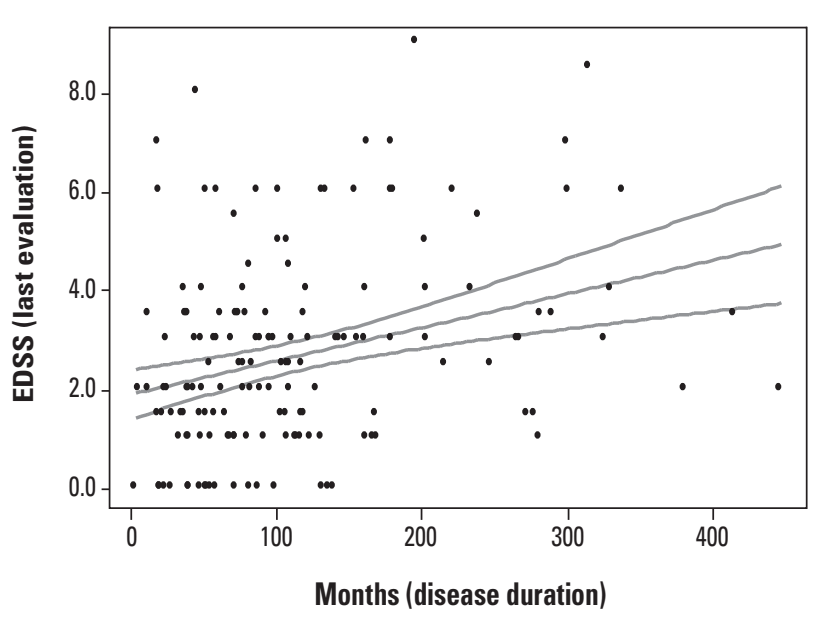

Fig 1. Linear regression of all 155 cases between disease duration (months) and the expanded disability status scale (EDSS) upon final evaluation with a 95\% mean prediction interval.

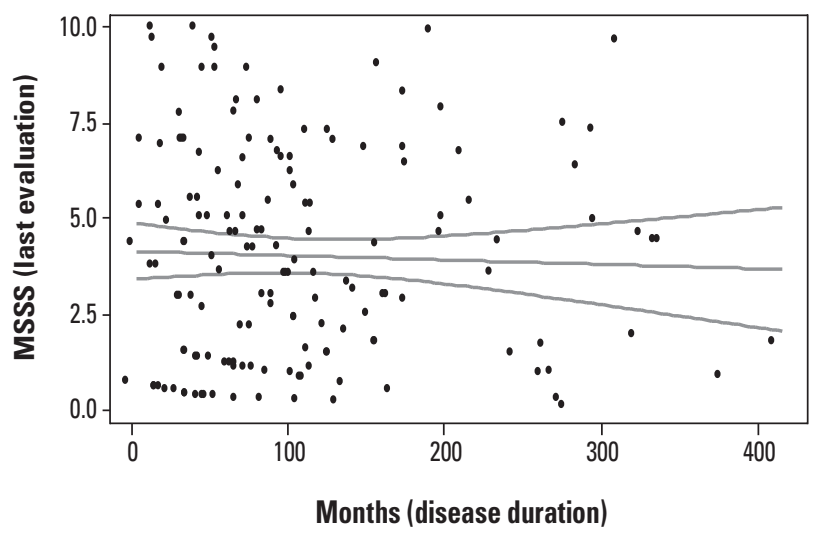

Fig 2. Linear regression of all 155 cases between disease duration (months) and the multiple sclerosis severity score (MSSS) upon final evaluation with a $95 \%$ mean prediction interval.

types, 18 cases with three treatment types, 7 cases with 4 treatment types and 1 case with five treatment types). The number of patients who had received AZA, R22, BET and SYT was greater than those treated by AVO, R44, COP and MIT (Table 1).

The age of treatment onset among the different groups was statiscally significant between the SYT group and the AZA ( $p=0.002)$, BET ( $\mathrm{p}=0.021), \mathrm{R} 22(\mathrm{p}=0.015)$, AVO $(\mathrm{p}=0.014)$ and $\mathrm{R} 44(\mathrm{p}=0.034)$ groups (Mann-Whitney $\mathrm{U}$ test, $\mathrm{p}<0.05)$. However, the age of treatment onset between AZA, BET, R22, AVO, R44, COP and MIT groups was not statiscally significant.

A statistically significant difference occurred with the time of disease progression before the treatment between the SYT group and AZA ( $\mathrm{p}=0.002), \mathrm{BET}(\mathrm{p}=0.021)$, R22 ( $\mathrm{p}=0.015)$, AVO ( $\mathrm{p}=0.014) \mathrm{R} 44(\mathrm{p}=0.034)$ and COP $(\mathrm{p}=0.170)$ on Mann-Whitney U test.

The AZA group had the longest time of use, followed by the SYT group, whereas the AVO and MIT groups 


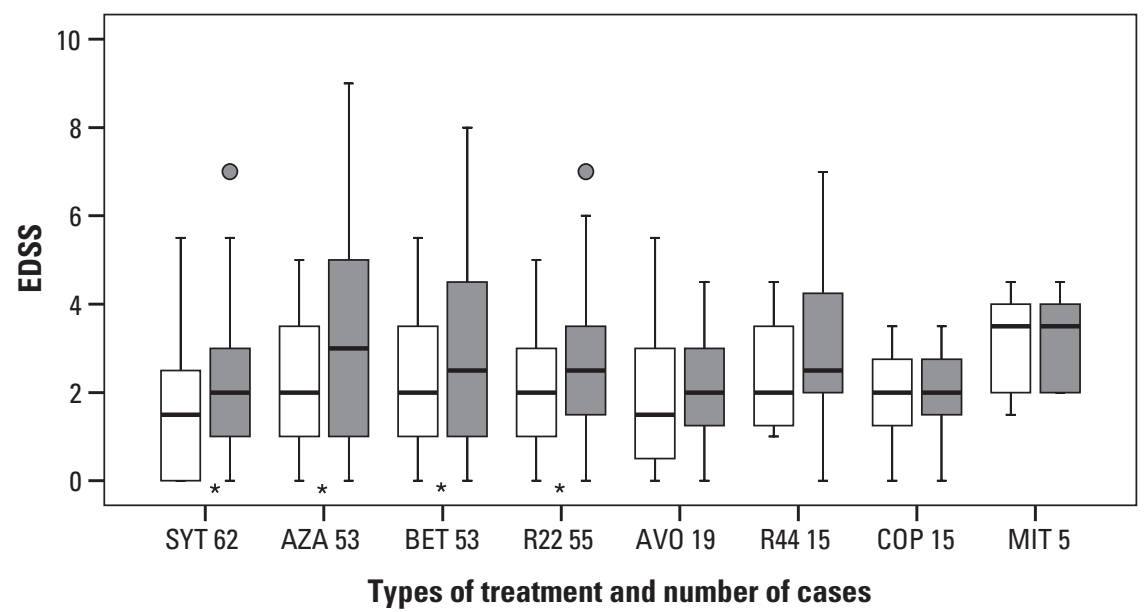

EDSS: expanded disability status scale; SYT: symptomatic treatment; AZA: Azathioprine $3 \mathrm{mg} / \mathrm{kg}$ q.d., PO; BET: interferon beta 1 b $250 \mu$ g q.o.d., SC; R22: interferon beta 1a $22 \mu \mathrm{g}$ t.i.W., SC; AVO: interferon beta 1 a $30 \mu \mathrm{g}$ q.W., IM; R44: interferon beta 1a $44 \mu \mathrm{g}$ t.i.w., SC; COP: glatiramer acetate $20 \mathrm{mg}$ q.d., SC; MIT: mitoxantrone $120 \mathrm{mg}$ in 18 months, IV; ${ }^{*} \mathrm{p}<0.001$; Wilcoxon Signed Ranks Test; $\mathbf{O}$ : outliers.

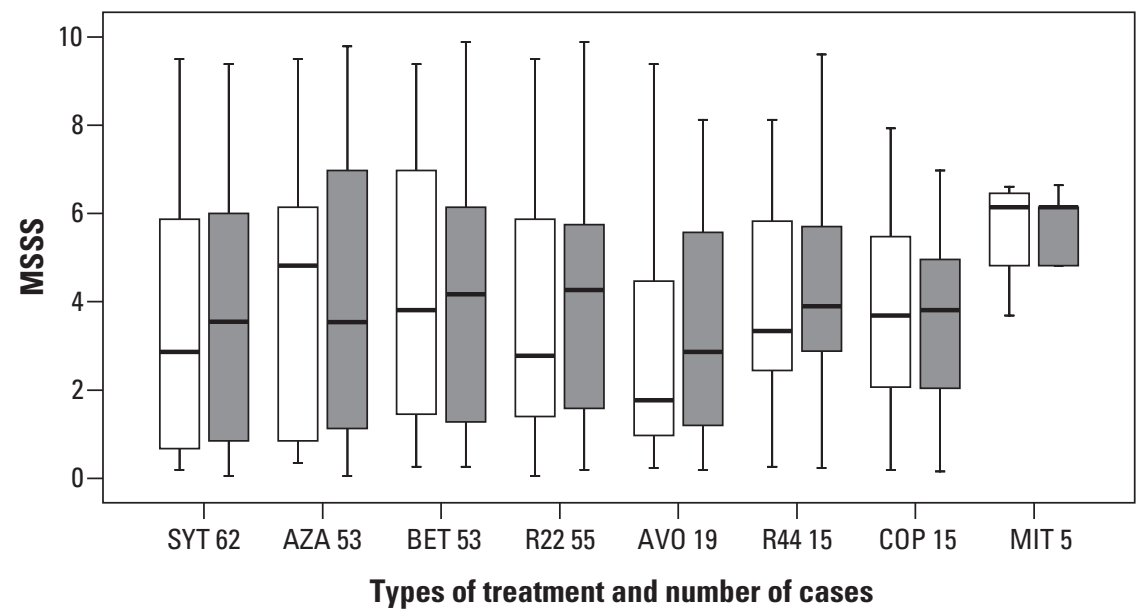

MSSS: multiple sclerosis severity score; SYT: symptomatic treatment; AZA: Azathioprine 3 mg/kg q.d., PO; BET: interferon beta $1 \mathrm{~b} 250 \mu \mathrm{g}$ q.o.d., SC; R22: interferon beta 1a $22 \mu \mathrm{g}$ t.i.w., SC; AVO: interferon beta $1 \mathrm{a} 30 \mu \mathrm{g}$ q.W., IM; R44: interferon beta 1a $44 \mu \mathrm{g}$ t.i.w., SC; COP: glatiramer acetate $20 \mathrm{mg}$ q.d., SC; MIT: mitoxantrone $120 \mathrm{mg}$ in 18 months, IV. Wilcoxon Signed Ranks Test.

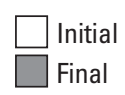

Fig 3. Initial and final EDSS for 277 different therapeutic procedures in multiple sclerosis patients. Box represents the interquartile range, containing 50\% of individual patient EDSS; whiskers lines points to the highest and lowest values, excluding outliers; lines across the box show medial values.

Fig 4. Initial and final MSSS for 277 different therapeutic procedures in multiple sclerosis patients. Box represents the interquartile range, containing $50 \%$ of individual patient MSSS; whiskers lines points to the highest and lowest values, excluding outliers; lines across the box show medial values. used the drug for the least amount of time (Table 1). There was statistical difference between the times of treatment in the SYT and AZA ( $\mathrm{p}=0.013)$, AVO ( $\mathrm{p}=0.048)$ and MIT $(\mathrm{p}=0.026)$ groups, and between AZA and all other drugs (BET $p=0.003, \mathrm{R} 22 \mathrm{p}=0.001$, AVO $\mathrm{p}=0.000, \mathrm{R} 44 \mathrm{p}=0.024$, COP $\mathrm{p}=0.001$, MIT $\mathrm{p}=0.001$ ). Also, there were statistical differences in the time of use between BET with AVO $(p=0.019)$ and MIT (0.023), as well as between MIT with R22 ( $\mathrm{p}=0.037$ and R44 ( $\mathrm{p}=0.019)$ (Mann-Whitney U test).

The initial mean treatment EDSS score was statiscally significant between the SYT group and AZA ( $\mathrm{p}=0.006)$, $\operatorname{BET}(\mathrm{p}=0.003), \mathrm{R} 44(\mathrm{p}=0.028)$ or MIT $(\mathrm{p}=0.021)$ groups, which had higher EDSS (Mann-Whitney U test).

The comparison between mean and median initial and final EDSS score for the whole group was statiscally significant $(\mathrm{p}=0.000)$, as well as for the sub-groups SYT, AZA, BET and R22. No statistical significance was found in the sub-groups of AVO, R44, COP and MIT between the initial and final evaluation (Fig 3).

When the disability between the initial and final scores was compared using the MSSS, no statistical difference was found for the whole group as well for the treatment sub-groups (Fig 4).

When the differences between initial and final EDSS and MSSS score were compared between the groups, we found no statistical significance difference between any groups (including the SYT group) (Mann-Whitney U test, Tables 2 and 3).

The difference from the initial and final EDSS score had statistical correlation with time of disease progres- 
Table 2. Difference between the initial and final EDSS among the types of treatments for 277 different therapeutic procedures in multiple sclerosis patients and statistical significance between the types of treatment.

\begin{tabular}{|c|c|c|c|c|c|c|c|c|}
\hline & $\begin{array}{l}\text { Difference (mean, } \\
\text { SD, median, range) }\end{array}$ & SYT & AZA & BET & $\mathrm{R} 22$ & AVO & R44 & COP \\
\hline $\begin{array}{l}\text { SYT } \\
62\end{array}$ & $\begin{array}{c}0.60 \pm 1.12 \\
0.00(-2 \text { to } 4)\end{array}$ & & & & & & & \\
\hline $\begin{array}{l}\text { AZA } \\
53\end{array}$ & $\begin{array}{c}0.97 \pm 1.81 \\
0.00(-4 \text { to } 5)\end{array}$ & 0.394 & & & & & & \\
\hline $\begin{array}{c}\text { BET } \\
53\end{array}$ & $\begin{array}{c}0.67 \pm 1.36 \\
0.00(-1.5 \text { to } 4)\end{array}$ & 0.668 & 0.360 & & & & & \\
\hline $\begin{array}{c}\mathrm{R} 22 \\
55\end{array}$ & $\begin{array}{c}0.78 \pm 1.22 \\
0.50(-1.5 \text { to } 4)\end{array}$ & 0.355 & 0.812 & 0.286 & & & & \\
\hline $\begin{array}{c}\text { AVO } \\
19\end{array}$ & $\begin{array}{c}0.24 \pm 1.02 \\
0.00(-2 \text { to } 2)\end{array}$ & 0.322 & 0.145 & 0.482 & 0.119 & & & \\
\hline $\begin{array}{c}\text { R44 } \\
15\end{array}$ & $\begin{array}{c}0.53 \pm 1.55 \\
0.00(-1 \text { to } 5)\end{array}$ & 0.509 & 0.376 & 0.712 & 0.273 & 0.864 & & \\
\hline $\begin{array}{l}\mathrm{COP} \\
15\end{array}$ & $\begin{array}{c}0.13 \pm 0.81 \\
0.00(-1 \text { to } 2)\end{array}$ & 0.173 & 0.132 & 0.334 & 0.062 & 0.784 & 0.624 & \\
\hline $\begin{array}{l}\text { MIT } \\
5\end{array}$ & $\begin{array}{c}0.30 \pm 0.45 \\
0.00(0 \text { to } 1)\end{array}$ & 0.737 & 0.628 & 0.979 & 0.418 & 0.836 & 0.933 & 0.612 \\
\hline $\begin{array}{l}\text { Total } \\
277\end{array}$ & $\begin{array}{c}0.66 \pm 1.35 \\
0.00(-4 \text { to } 5)\end{array}$ & & & & & & & \\
\hline
\end{tabular}

EDSS: expanded disability status scale; SYT: symptomatic treatment; AZA: Azathioprine 3 mg/kg q.d., PO; BET: interferon beta 1b 250 $\mu$ g q.o.d., SC; R22: interferon

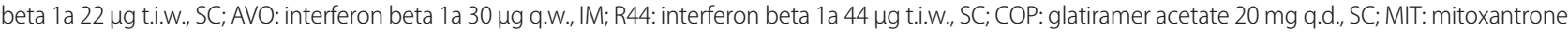
$120 \mathrm{mg}$ in 18 months, IV. Bold numbers: $\mathrm{p}<0.05$ (Mann-Whitney $\mathrm{U}$ test).

Table 3. Difference between the initial and final MSSS among the types of treatments for 277 different therapeutic procedures in multiple sclerosis patients and statistical significance between the types of treatment.

\begin{tabular}{|c|c|c|c|c|c|c|c|c|}
\hline & $\begin{array}{l}\text { Difference (mean, SD, median, } \\
\text { maximum-minimum) }\end{array}$ & SYT & AZA & BET & R22 & Avo & R44 & COP \\
\hline $\begin{array}{l}\text { SYT } \\
62\end{array}$ & $\begin{array}{c}-0.07 \pm 2.19 \\
-0.22(-6.68-7.31)\end{array}$ & & & & & & & \\
\hline $\begin{array}{c}\text { AZA } \\
53\end{array}$ & $\begin{array}{c}0.09 \pm 2.70 \\
-0.18(-8.37-7.47)\end{array}$ & 0.619 & & & & & & \\
\hline $\begin{array}{c}\text { BET } \\
53\end{array}$ & $\begin{array}{c}0.10 \pm 1.97 \\
-0.24(-4.96-7.47)\end{array}$ & 0.866 & 0.555 & & & & & \\
\hline $\begin{array}{c}\text { R22 } \\
55\end{array}$ & $\begin{array}{c}0.34 \pm 2.20 \\
0.00(-4.59-7.09)\end{array}$ & 0.228 & 0.585 & 0.198 & & & & \\
\hline $\begin{array}{c}\text { AVO } \\
19\end{array}$ & $\begin{array}{c}0.39 \pm 2.04 \\
-0.14(-2.40-6.14)\end{array}$ & 0.590 & 0.730 & 0.553 & 0.837 & & & \\
\hline $\begin{array}{l}\text { R44 } \\
15\end{array}$ & $\begin{array}{c}0.17 \pm 2.03 \\
-0.14(-1.78-6.24)\end{array}$ & 0.906 & 0.916 & 0.829 & 0.427 & 0.791 & & \\
\hline $\begin{array}{c}\mathrm{COP} \\
15\end{array}$ & $\begin{array}{c}-0.29 \pm 1.64 \\
-0.15(-2.69-4.15)\end{array}$ & 0.604 & 0.590 & 0.840 & 0.194 & 0.498 & 0.602 & \\
\hline $\begin{array}{c}\text { MIT } \\
5\end{array}$ & $\begin{array}{c}0.17 \pm 0.59 \\
0.00(-0.47-1.13)\end{array}$ & 0.229 & 0.702 & 0.340 & 0.979 & 0.526 & 0.542 & 0.229 \\
\hline $\begin{array}{l}\text { Total } \\
277\end{array}$ & $\begin{array}{c}0.07 \pm 2.19 \\
-0.15(-8.37-7.47)\end{array}$ & & & & & & & \\
\hline
\end{tabular}

MSSS: multiple sclerosis severity score; SYT: symptomatic treatment; AZA: Azathioprine $3 \mathrm{mg} / \mathrm{kg}$ q.d., PO; BET: interferon beta $1 \mathrm{~b} 250$ $\mu$ g q.o.d., SC; R22: interferon

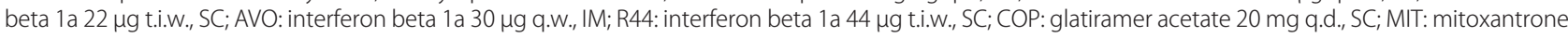
120 mg in 18 months, IV. Bold numbers: $\mathrm{p}<0.05$ (Mann-Whitney $\mathrm{U}$ test). 
Table 4. Correlation of differences from EDSS and MSSS (initial and final) with time of progression in months for 277 different therapeutic procedures in multiple sclerosis patients.

\begin{tabular}{|c|c|c|c|c|}
\hline & $\begin{array}{l}\text { Difference EDSS/ } \\
\text { Time of treatment }\end{array}$ & $p=*$ & $\begin{array}{l}\text { Difference MSSS/ } \\
\text { Time of treatment }\end{array}$ & $p=*$ \\
\hline $\begin{array}{l}\text { SYT } \\
62\end{array}$ & 0.244 & 0.056 & -0.274 & 0.031 \\
\hline $\begin{array}{c}\text { AZA } \\
53\end{array}$ & 0.440 & 0.001 & -0.59 & 0.674 \\
\hline $\begin{array}{c}\mathrm{BET} \\
53\end{array}$ & 0.305 & 0.026 & -0.59 & 0.676 \\
\hline $\begin{array}{l}\mathrm{R} 22 \\
55\end{array}$ & 0.258 & 0.057 & -0.77 & 0.576 \\
\hline $\begin{array}{c}\text { AVO } \\
19\end{array}$ & 0.107 & 0.663 & 0.10 & 0.967 \\
\hline $\begin{array}{c}\text { R44 } \\
15\end{array}$ & -0.036 & 0.898 & 0.120 & 0.670 \\
\hline $\begin{array}{l}\text { COP } \\
15\end{array}$ & -0.087 & 0.759 & -0.127 & 0.652 \\
\hline $\begin{array}{c}\text { MIT } \\
5\end{array}$ & -0.238 & 0.700 & -0.322 & 0.597 \\
\hline $\begin{array}{c}\text { Total } \\
277\end{array}$ & 0.203 & 0.001 & -0.116 & 0.054 \\
\hline
\end{tabular}

EDSS: expanded disability status scale; MSSS: multiple sclerosis severity score; p: statistical significance; SYT: symptomatic treatment; AZA: Azathioprine $3 \mathrm{mg} / \mathrm{kg}$ q.d., PO; BET: interferon beta $1 \mathrm{~b} 250$ g q.o.d., SC; R22:

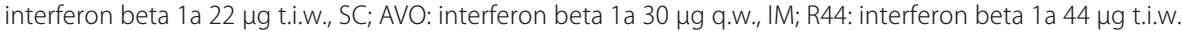
SC; COP: glatiramer acetate $20 \mathrm{mg}$ q.d., SC; MIT: mitoxantrone $120 \mathrm{mg}$ in 18 months, IV. Bold numbers: $p<0.05$. (Pearson correlation $r$ test).

Table 5. Variation in initial and final EDSS and MSSS for 277 different therapeutic procedures in multiple sclerosis patients.

\begin{tabular}{|c|c|c|c|c|c|c|}
\hline & \multicolumn{3}{|c|}{ EDSS } & \multicolumn{3}{|c|}{ MSSS } \\
\hline & Reduction (\%) & Unchanged (\%) & Increased (\%) & Reduction (\%) & Unchanged (\%) & Increased (\%) \\
\hline SYT & $7(11.3)$ & $29(46.8)$ & $26(41.9)$ & $37(59.7)$ & $6(9.7)$ & $19(30.6)$ \\
\hline AZA & $8(15.1)$ & $20(37.7)$ & $25(47.2)$ & $30(56.6)$ & $0(0.0)$ & $23(43.4)$ \\
\hline BET & $8(15.1)$ & $24(45.3)$ & $21(39.6)$ & $31(58.5)$ & $5(9.4)$ & $17(32.1)$ \\
\hline R22 & $9(16.4)$ & $15(27.3)$ & $31(56.4)$ & $27(49.1)$ & $1(1.8)$ & $27(49.1)$ \\
\hline AVO & $4(21.1)$ & $8(42.1)$ & $7(36.8)$ & $12(63.2)$ & $0(0.0)$ & $7(36.8)$ \\
\hline R44 & $4(26.7)$ & $4(26.7)$ & $7(46.7)$ & $9(60.0)$ & $0(0.0)$ & $6(40.0)$ \\
\hline COP & $3(20.0)$ & $7(46.7)$ & $5(33.3)$ & $9(60.0)$ & $1(6.7)$ & $5(33.3)$ \\
\hline MIT & $0(0.0)$ & $3(60.0)$ & $2(40.0)$ & $1(20.0)$ & $2(40.0)$ & $2(40.0)$ \\
\hline $\begin{array}{c}\text { Total } \\
277\end{array}$ & $43(15.5)$ & $110(39.7)$ & $124(44.8)$ & $156(56.3)$ & $15(5.4)$ & $106(38.3)$ \\
\hline
\end{tabular}

EDSS: expanded disability status scale; MSSS: multiple sclerosis severity scale; SYT: symptomatic treatment; AZA: Azathioprine 3 mg/kg q.d., PO; BET: interferon

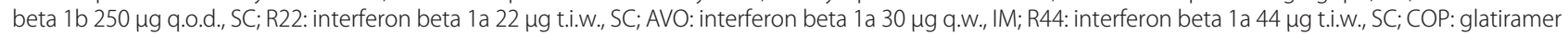
acetate $20 \mathrm{mg}$ q.d., SC; MIT: mitoxantrone $120 \mathrm{mg}$ in 18 months.

sion in months for the whole group of treatment, as well as for the sub-groups AZA and BET (Pearson's correlation $r$ test, Table 4 and Fig 5). However, with the MSSS the only group who had a statistical significance was the SYT sub-group (Table 4 and Fig 6).

The variation between the initial and final EDSS scores showed a reduction in 43 patients (15.5\%), no change in 110 (39.7\%), and an increase in 124 (44.8\%) (Table 5).
When with the use of the MSSS, we found a reduction in 156 (56.3\%) cases, unchanged in 15 (5.4\%) and increased in 106 (38.3\%) (Table 5)

\section{DISCUSSION}

This series presents demographic and clinical characteristics similar to those already published. The final EDSS score showed variation for the reduction of disabil- 

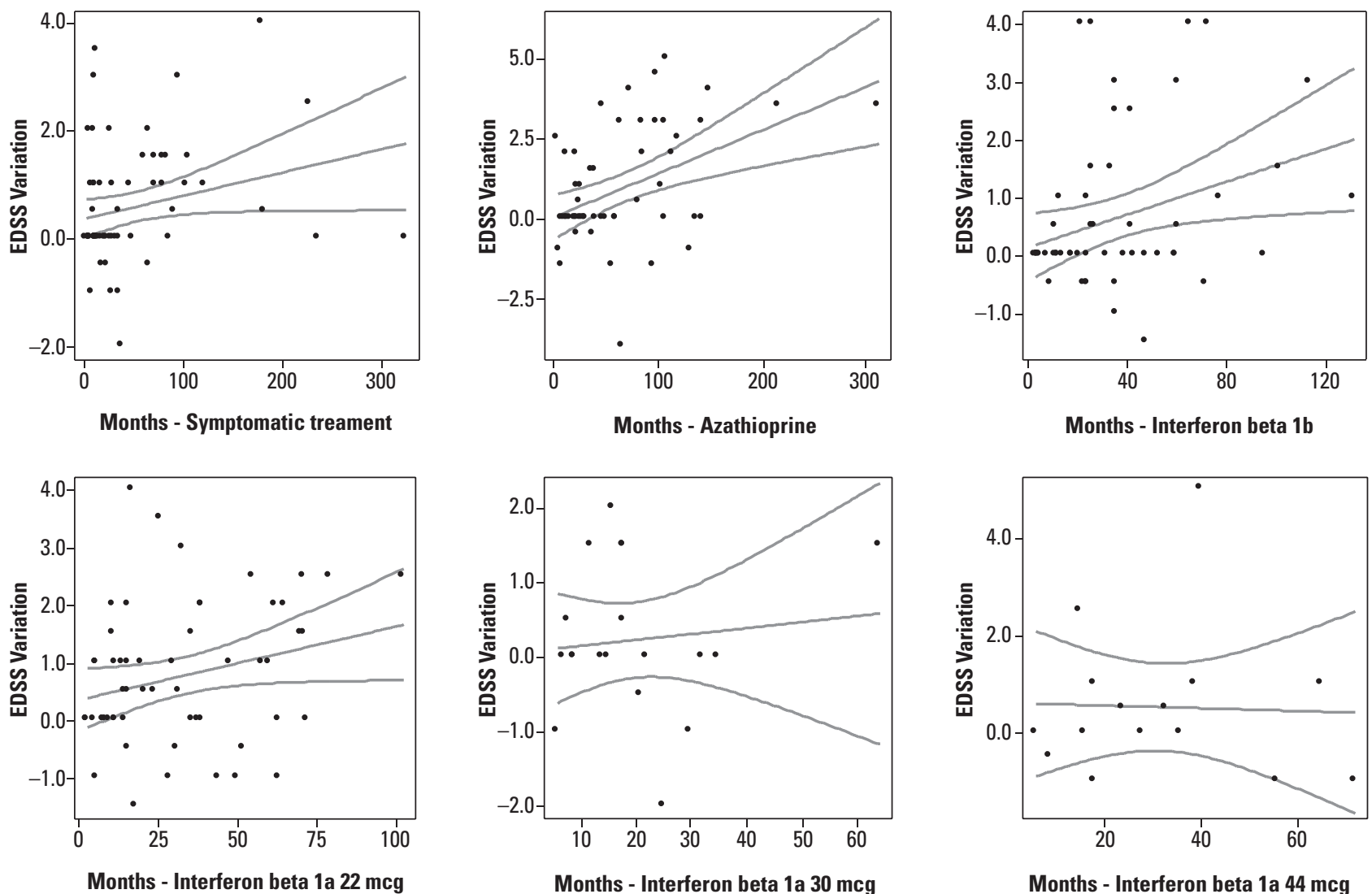

Months - Interferon beta 1a $44 \mathrm{mcg}$

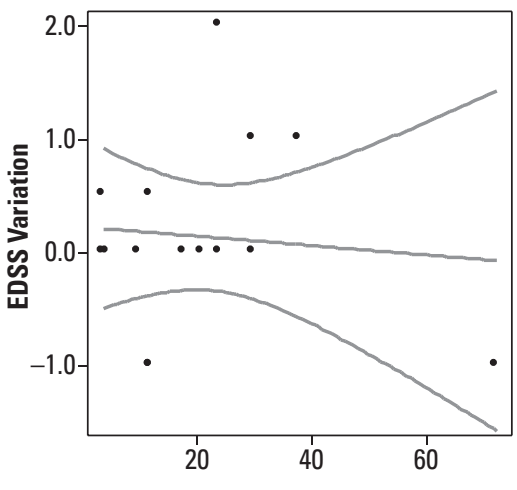

Months - Glatiramer acetate $20 \mathrm{mg}$

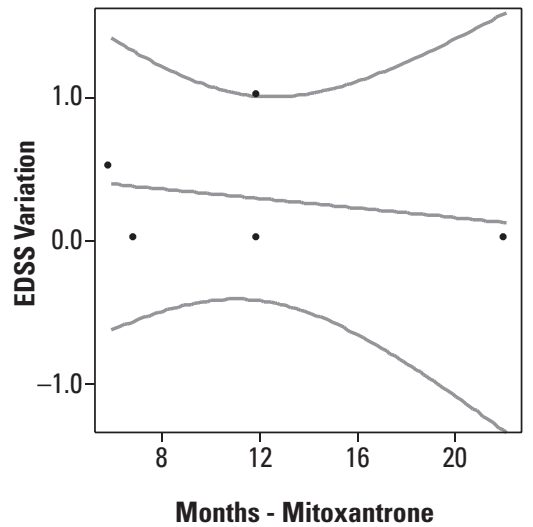

Fig 5. Correlation among the Expanded Disability Status Scale (EDSS) variation in each type and time of treatment. Linear regression with a 95\% mean prediction interval. ity up to four points and increased until five points, and a similar variation occurred with several IMM drugs?

We had an asymmetry of treatment groups regarding the number of patients because some drugs had been made available later for general use. The time spent exhibiting the first symptoms and seeking medical help was variable for these SYT patients, which was partially due to the fact that they did not have residual neurological deficits or additional relapses. Some of these patients received treatment with corticosteroids during their MS relapse and presented with a complete clinical remission or minimal residual neurological deficits. This is probably the reason these individuals remained in the SYT group for several years. Also, we should remember that corticosteroids also have an IMS and anti-inflammatory effect, promoting the regulation of $\mathrm{T}$ cells, acting in the bloodbrain barrier, the microglia and T-cell apoptosis, changing the natural course of the disease $\mathrm{e}^{31-35}$.

The difference in the time of treatment for each group probably occurred because of the following reasons: [1] for many years, no other choice of therapy was available; [2] the IMM was withdrawn when the EDSS was 6.5 (by Brazilian National Health System protocol); and [3] patients who showed intolerance or adverse effects were 

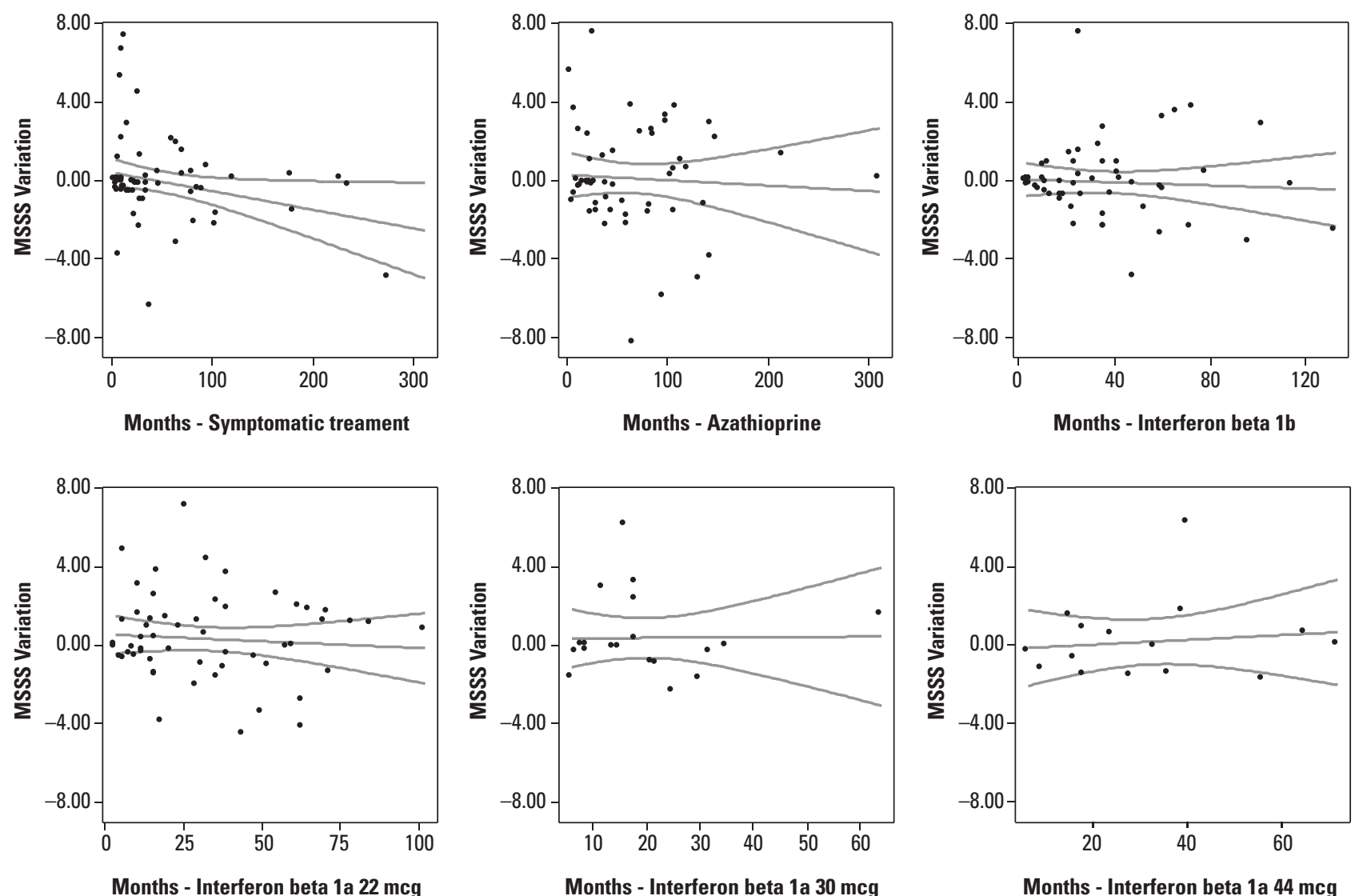

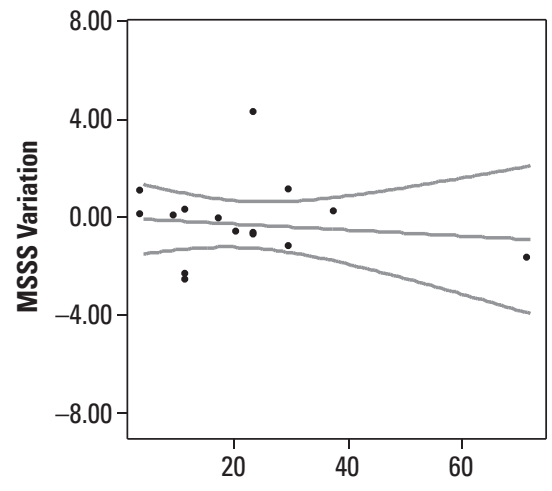

Months - Glatiramer acetate $20 \mathrm{mg}$

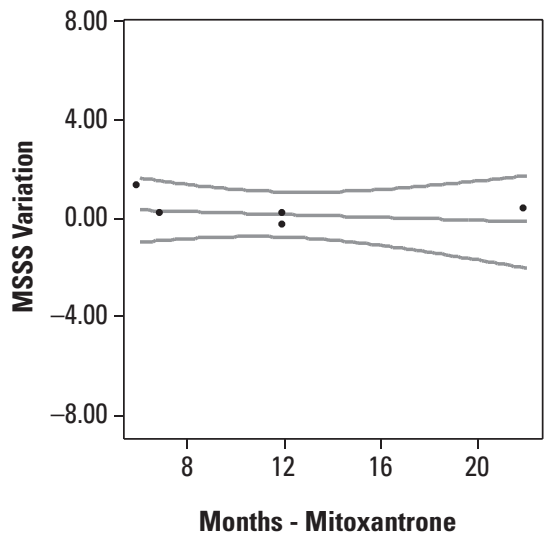

Fig 6. Correlation among the Multiple Sclerosis Severity Score (MSSS) variation in each type and time of treatment. Linear regression with a $95 \%$ mean prediction interval. maintained with AZA. Also the initial mean EDSS score was lower in the SYT group because the majority of patients were in the early stage of disease.

The lack of statistical difference between initial and final treatment score in the EDSS for some groups (AVO, R44, COP and MIT), could suggest disease stabilization or a reduction of disabilities, but these groups had less patients than the others with statistical significant data. In contrast, there was a positive statistical relation for other groups (SYT, AZA, BET, R22), which may indicate lower effectiveness of the drug with increasing disabilities. However, when the MSSS score was compared at the be- ginning and at end of the treatment, no statistical difference was found, as well as the difference between initial and final EDSS and MSSS. The positive correlation of the EDSS with time of treatment and some sub-groups could be interpreted as progression of disability, while the negative correlation could be reduction or stabilization. With the MSSS the time of disease already is calculated and we expected a reduction or stabilization of disability score with the treatment.

The progressive disability in MS over the long-term is well-recognized, but the time of progression is variable and depends on the patient ${ }^{29}$. IMM and IMS drugs reduce 
the number of relapses, but there is still controversy as to whether these drugs exert a significant influence on the long-term disabilities suffered by some MS patients ${ }^{36}$.

The major difficulty find consistent data on long term efficacy of IMS or IMS is to follow patients for a long period of time, because most clinical trials have a short duration (2 to 4 years) or the degrees of disability are too small and it is not possible to conclude or measure if potential therapeutic options are effective after a long period ${ }^{28}$. The introduction of new criteria for the clinical and imaging diagnosis have changed the course for MS treatment and disease progression because some drugs must be used early in cases of clinically isolated syndromes ${ }^{37,38}$.

We evaluated the progression of disability using the EDSS score ${ }^{24}$ because this index can be recorded based on the clinical manifestation and neurological examination recorded in the past decades.

There are few reports with longer follow up periods using the EDSS score, but all showed variable progression and stabilization of EDSS score in approximately $30 \%$ of patients after 5 years $^{27}, 8$ years $^{39}$ and 10 years $^{26,40}$. In these reports, a large number of patients did not finish the survey, and it raised the possibility that patients who remained in these studies had a good response and continued their medication.

Another study that used BET over a period of 16 years also showed a progression in disability, but demonstrated that individuals achieved the same degree of disability when using the medication for a period of 4.7 years $^{28,41}$.

Most of the studies used the EDSS as an index of disability to detect reduction, stabilization or progression. However, with the use of the MSSS, is possible to compare cases with the same EDSS in relation to time of disease ${ }^{30,42}$. Similar to our results, a study of 195 patients with a mean duration of symptoms of 9.7 years ( 0.3 to 26 years), a mean EDSS score of 3.5 and the majority using IMM drugs found no evidence that these drugs can influence disease disabilities using this new score ${ }^{43}$.

This study has some features that must be considered in the final conclusions, such as the asymmetry between certain groups with a greater number of patients. Furthermore, this was not a blind study, nor was it fully prospective or randomized ${ }^{28,44}$. However, this study is important from an economic aspect because of the cost of drugs in relation to the benefits, and report the clinical management of an average Brazilian medical center, where the patients and physicians change the type of treatment for several reasons ${ }^{7,30,45}$.

The progression of the disease does not seem to depend only on the inflammatory reaction, but also on an independent degenerative process that provides progressive axonal transection ${ }^{46}$, perhaps related to some immunogenetic factors ${ }^{47,48}$. To answer these questions will re- quire studies correlating antibodies against interferon, the major histocompatibility complex and additional pharmacogenetic studies.

The result of our data showed no statistically significant differences in disease progression among the several drugs used for MS treatment when the variation in the difference between the initial and final EDSS and MSSS score was considered, including the group who received only corticosteroids, who we considered as symptomatic therapy. Some cases stabilized and even showed a reduction in long-term disability, according the type of scale used. However, the question remains if these changes occurred due to the natural course of the disease, the influence of interferon antibodies, individual immunogenetic factors, drug effects, or the prolonged use of corticosteroids for relapse.

\section{REFERENCES}

1. Casetta I, Iuliano G, Filippini G. Azathioprina for multiple sclerosis. Cochrane Database Syst Rev 2007;CD003982.

2. Ellison GW, Myers LW, Mickey ME, et al. A placebo-controlled, randomized, double-masked, variable dosage, clinical trial of azathioprine with and without methylprednisolone in multiple sclerosis. Neurology 1989;39:1018-1026.

3. Goodkin DE, Bailly RC, Teetzen ML, Hertsgaard D, Beatty WW. The efficacy of azathioprine in relapsing-remitting multiple sclerosis. Neurology 1991;41:20-25.

4. Milanese C, La Mantia L, Salmaggi A, Eoli M. A double blind study on azathioprine efficacy in multiple sclerosis: final report. J Neurol 1993;240:20-25.

5. Fox EJ. Management of worsening multiple sclerosis with mitoxantrone: a review. Clin Ther 2006;28:461-474.

6. Le Page E, Leray E, Taurin G, et al. Mitoxantrone as induction treatment in aggressive relapsing multiple sclerosis: treatment response factors in a 5 years follow-up observational study of 100 consecutive patients. J Neurol Neurosurg Psychiatry 2008;79:52-56.

7. Pickin M, Cooper $\mathrm{CL}$, Chater $\mathrm{T}$, et al. The multiple sclerosis risk sharing scheme monitoring study: early results and lessons for the future. BMC Neurology 2009;9:1.

8. The IFNB Multiple Sclerosis Study Group. Interferon beta- $1 \mathrm{~b}$ is effective in relapsing-remitting multiple sclerosis: I. Clinical results of a multicenter, randomized, double-blind, placebo-controlled trial. Neurology 1993;43:655-661.

9. Jacobs LD, Cookfair DL, Rudick RA, et al. A phase III trial of intramuscular recombinant interferon beta as treatment for exacerbating-remitting multiple sclerosis: design and conduct of study and baseline characteristics of patients. Multiple Sclerosis Collaborative Research Group (MSCRG). Mult Scler 1995:1:118-135.

10. Jacobs LD, Cookfair DL, Rudick RA, et al. Intramuscular interferon beta-1a for disease progression in relapsing multiple sclerosis. Ann Neurol 1996;39:285-294.

11. Simon JH, Jacobs LD, Campion M, et al. Magnetic resonance studies of intramuscular interferon beta-1a for relapsing multiple sclerosis: the Multiple Sclerosis Collaboration Research Group. Ann Neurol 1998;43:79-87.

12. PRISMS Study Group. Randomised double-blind placebo-controlled study of interferon b-1a in relapsing/remitting multiple sclerosis. Lancet 1998;352: 1498-1504.

13. Panitch H, Goodin DS, Francis G, et al. Randomised, comparative study of interferon beta-1a treatment regimens in MS: The EVIDENCE Trial. Neurology 2002:59:1496-1506.

14. Schwid SR, Panitch HS. Full results of the evidence of Interferon Dose-Response-European North AmericanComparative Efficacy (EVIDENCE) Study: a multicenter, randomized, assessor-blinded comparison of low-dose weekly versus high-dose, high-frequency interferon beta-1a for relapsing multiple sclerosis. Clin Ther 2007;29:2031-2048.

15. Durelli $L$, Verdun $E$, Barbero $P$, et al. Every-other-day interferon beta- 1 b versus once-weekly interferon beta-1a for multiple sclerosis: results of a 2-year prospective randomized multicentre study (INCOMIN). Lancet 2002;359:1453-1460.

16. Johnson KP, Brooks BR, Cohen JA, et al. Copolymer 1 reduces relapse rate and imwoves disability in relapsing-remitting multiple sclerosis: results of a phase III multicenter, double-blind, placebo-controlled trial. Neurology 1995; 45:1268-1276 
17. Mikol DD, Varkhof F, Chang P, et al. Comparison of subcutaneous interferon beta-1a with glatiramer acetate in patients with relapsing multiple sclerosis (the REbif vs Glatiramer Acetate in relapsing MS disease [REGARD] study): a multicentre, randomised, parallel, open-label trial. Lancet Neurol 2008;7:903-914.

18. Flecter S, Vardi J, Pollak L, Rabey JM. Comparison of glatiramer acetate (Copaxone) and interferon beta-1b (Betaferon) in multiple sclerosis patients: an open-label 2 year follow-up. J Neurol Sci 2002;197:51-55.

19. Daumer M, Neuhaus A, Morrissey S, Hintzen R, Ebers GC. MRI as an outcome in multiple sclerosis clinical trials. Neurology 2009;72:705-711.

20. Paty DW, Li DK. Interferon beta- $1 \mathrm{~b}$ is effective in relapsing-remitting multiple sclerosis. II. MRI analysis results of a multicenter, randomized, doubleblind, placebo-controlled trial. UBC MS/MRI Study Group and the IFNB Multiple Sclerosis Study Group. Neurology 1993;43:662-667.

21. Li DK, Paty DW. Magnetic resonance imaging results of the PRISMS trial: a randomized, double-blind, placebo-controlled study of interferon-beta1a in relapsing-remitting multiple sclerosis: prevention of relapses and disability by interferon-beta1a subcutaneously in multiple sclerosis. Ann Neurol 1999;46:197-206

22. Filippi M, Wolinsky JS, Comi G, the CORAL Study Group. Effects of oral glatiramer acetate on clinical and MRI monitored disease activity in patients with relapsinf multiple sclerosis: a multicenter, double-blind, randomized, placebo-controlled study. Lancet Neurol 2006;5:213-220.

23. Massacesi L, Parigi A, Barilaro A, et al. Efficacy of azthioprine on multiple sclerosis new brain lesion evaluated using magnetic resonance imaging. Arch Neurol 2005;62:1843-1847.

24. Kurtzke JF. Rating neurologic impairment in multiple sclerosis: an expanded disability status scale (EDSS). Neurology 1983;33:1444-1452.

25. PRISMS Study Group and the University of British Columbia MS/MRI Analysis Group. PRISMS-4: long-term efficacy of interferon-beta-1a in relapsing MS. Neurology 2001;56:1628-1636

26. Miller A, Spada V, Beerkircher D, Kreitman RR. Long-term (up to 22 years), open-label, compassionate-use study of glatiramer acetate in relapsing-remitting multiple sclerosis. Mult Scler 2008;14:494-499.

27. Johnson KP, Brooks BR, Ford CC, et al. Sustained clinical benefits of glatiramer acetate in relapsing multiple sclerosis patients observed for 6 years. Copolymer 1 Multiple Sclerosis Study Group. Mult Scler 2000;6:255-266.

28. Ebers GC, Heigenhauser L, Daumer M, Lederer C, Noseworthy JH. Disability as an outcome in MS clinical trials. Neurology 2008;71:624-631.

29. Lublin FD, Reingold SC. Defining the clinical course of multiple sclerosis: results of an internacional survey. Neurology 1996;46:907-911.

30. Roxburgh RHSR, Seaman SR, Masterman T, et al. Multiple sclerosis severity score: using disability and disease duration to rate disease severity. Neurology 2005;64:1144-1151.

31. $\mathrm{Xu} \mathrm{L,} \mathrm{Xu} \mathrm{Z,} \mathrm{Xu} \mathrm{M.} \mathrm{Glucocorticoid} \mathrm{treatment} \mathrm{restores} \mathrm{the} \mathrm{impaired} \mathrm{suppres}$ sive function of regulatory $T$ cells in patients with relapsing-remitting multiple sclerosis. Clin Exp Immunol 2009;158:26-30
32. Reichardt HM, Gold R. Lühder F. Glucocorticoids in multiple sclerosis and experimental autoimmune encephalomyelitis,. Expert Rev Neurother 2006;6: 1657-1670.

33. Lühder F, Reichardt HM. Traditional concepts and future avenues of glucocorticoid action in experimental autoimmune encephalomyelitis and multiple sclerosis therapy. Crit Rev Immunol 2009;29:255-273.

34. Xu J, Chen H, Xiao Q, Hsu CY, Michael D, Bao J. STAT5 mediates antiapoptotic effects of methylprednisolone on oligodencrocytes. J Neurosci 2009;29: 2022-2026.

35. Sloka JS, Stefanelli M. The mechanism of action of methylprednisolone in the treatment of multiple sclerosis. Mult Scler 2005:11:425-432.

36. Brown MG, Kirby S, Skedgel C, et al. How effective are disease-modifying drugs in delaying progression in relapsing-onset MS. Neurology 2007;69: 1498-1507.

37. McDonald WI, Compston A, Edan G, et al. Recommended diagnostic criteria for multiple sclerosis: guidelines from the International panel on the diagnosis of multiple sclerosis. Ann Neurol 2001;50:121-127.

38. Polman CH, Reingold SC, Edan G, et al. Diagnostic criteria for multiple sclerosis: 2005 revision to the "McDonald Criteria". Ann Neurol 2005;58:840-846.

39. Johnson KP, Ford CC, Lisak RP, Wolinsky JS. Neurologic consequence of delaying glatiramer acetate therapy for multiple sclerosis: 8-year data. Acta Neurol Scand 2005:111:42-47.

40. Ford CC, Johnson KP, Lisak RP, Panitch HS, Shironi G, Wolinski JS, The Copaxone Study Group: a prospective open-label study of glatiramer acetate: over a decade of continuous use in multiple sclerosis patients. Mult Scler 2006;12:309-320

41. Ebers $\mathrm{G}$, Rice $\mathrm{G}$, Konieczny A, et al. The interferon beta-1b 16-years long-term follow-up study: the final results. Neurology 2006;66(Suppl 2):S32.

42. Daumer M, Neuhais A, Herbert J, Ebers G. Prognosis of the individual course of disease: the elements of time, hetereogeneity and precision. J Neurol Sci 2009:287(Suppl 1):S50-S55

43. Pachner AR, Steiner I. The multiple sclerosis severity score (MSSS) predicts disease severity over time. J Neurol Sci 2009;278:66-70

44. Goodin DS. Disease-modifying therapy in MS: a critical review of the literature. Part Il: assessing efficacy and dose-response. J Neuro I 2004;251(Suppl 5):S50-S56.

45. Bell C, Graham J, Earnshaw S, Oleen-Burkey MK, Castelli-Haley J, Johnson K. Cost-effectiveness of four immunomodulatory therapies for relapsing-remitting multiple sclerosis: a Makov model based on long-term clinical data. J Manag Care Pharm 2007;13:245-261

46. Trapp BD, Peterson J, Ransohoff RM, Rudick R, Mörk S, Bö L. Axonal transection in the lesions of multiple sclerosis. N Engl J Med 1998;338:323-325.

47. Minagar A, Amor S, Zivadinov R. Gray matter pathology in (chronic) MS: modern views on an early observation. J Neurol Sci 2009;282:12-20.

48. Zivadinov R, Weinstock-Guttman B, Zorzon M, et al. Gene-environment interactions between HLA B7/A2, EBV antibodies are associated with MRI injury in multiple sclerosis. J Neuroimmunol 2009;209:123-130. 